\title{
Participation in Activities and Autonomy with an Impact toward Task Performance and Contextual Performance among Engineers
}

\author{
Nasina Mat Desa ${ }^{1}$, Muhammad Hasmi Abu Hassan Asaari ${ }^{1}$ \& Azley Abd Razak ${ }^{2}$ \\ ${ }^{1}$ Management Section, School of Distance Education, Universiti Sains Malaysia, Malaysia \\ ${ }^{2}$ Faculty of Business and Society, University of South Wales, Pontypridd, Cardiff, Newport, United Kingdom \\ Correspondence: Muhammad Hasmi Abu Hassan Asaari, Management Section, School of Distance Education, \\ Universiti Sains Malaysia, Malaysia. E-mail: hasmi@usm.my
}

Received: September 12, 2019

doi:10.5539/ijbm.v14n12p79

\author{
Accepted: October 14, 2019 Online Published: November 8, 2019 \\ URL: https://doi.org/10.5539/ijbm.v14n12p79
}

\begin{abstract}
This study explores the relationship and the impact of the participation in related activities and autonomy of job performance toward task performance and contextual performance of job performance. The study was conducted on the electrical and electronics (E\&E) engineers in the Bayan Lepas Free Trade Zone, Penang. Self-administered questionnaires were distributed through the E\&E manufacturing companies' human resource managers. A total of 1,100 questionnaires were distributed that adapted and adopted the research tools of Govino on participation in related activities, Conway and Monks on autonomy, Williams and Anderson on task performance, and Hochwarter et al. on contextual performance. A total of 181 were returned but 150 questionnaires were useable for this study. A factor analysis was conducted on all variables of the study. Interestingly, participation in work-related variables had been divided into participation in HR-related activities and participation in work-related activities. Results indicated that participation in HR-related activities had no association with task performance but had a low relationship with the contextual performance. Furthermore, the participation in work-related activities had no relationship with both, the task performance and the contextual performance. Finally, the engineers indicated that their autonomy had a low relationship with the task performance and moderate relationship with the contextual performance.
\end{abstract}

Keywords: HR-related activities, work-related activities, autonomy, task performance, contextual performance

\section{Introduction}

According to Malaysia Industrial Development Authority's report (MIDA, 2009), the electronics industry was the leading sector in Malaysia's manufacturing sector, contributing significantly to the country's manufacturing output (29.3 per cent), exports (55.9 per cent) and employment 28.8 per cent). The gross output of the industry totaled RM167.2 billion (US\$53.9 billion), exports amounted to RM233.8 billion (US\$75.4 billion) and the industry created employment opportunities for 296,870 people. In 2008, Malaysia exported electrical and electronic (E\&E) products valued at RM13.74 billion (US\$3.8 billion) while import products for electrical and electronic products valued at RM10.28 (US\$2.8 billion). Hence, this signifies the importance of looking into the E\&E industry, in particular, the employee in this industry. Specifically, the performance of the engineers as it is the largest pool of executive in a manufacturing organization; consist of $50 \%$ of the E\&E industry in the northern region of Malaysia (FMM, 2007/2008) was considered as a substantial number of engineers in the E\&E for the nation.

Furthermore, human resources are considered the most important asset of an organization, but very few organizations can fully harness its potential. Lado and Wilson (1994) define a human resources system as a set of distinct but interrelated activities, functions, and processes that are directed at attracting, developing, and maintaining or disposing of a firm's human resources. Traditionally, management of this system has gained more attention from service organizations than from manufacturing organizations. However, to enhance operational performance and overall job performance, effectively managing this system is equally important in both types of organizations. Needless to say, sophisticated technologies and innovative manufacturing practices alone can do very little to enhance operational and job performance unless the requisite human resource management (HRM) practices are in place to form a consistent socio-technical system. For this reason, manufacturing organizations need to carefully evaluate their existing HRM practices and modify them, if needed, so that employees can 
effectively contribute to overall job performance improvement. For this reason, also, the researcher would like to shed some lights in discovering the relationship between human resource practices and individual work performance.

According to the Federation of Malaysia Manufacturer's (FMM, 2007/2008), one of the real business problem faced by $\mathrm{E} \& \mathrm{E}$ industry is poor performance among engineers. Among the indicators of the poor performance is the delaying work completion such as unable to meet deadlines, dropping numbers of "excellent" rating in the engineers' performance appraisal to "average" rating, and delaying of megaprojects' decision making. Moreover, the compilation of the KPI (key performance index) of the FMM member's Human resource department's half-yearly report (FMM, 2007/2008) revealed that the performance of their engineers had shown a drop of 20 to 25 per cent in their key performance area (FMM, 2007/2008). The key performance areas are the task performance area; such as product knowledge, product design knowledge and ability to ensure all designs have considered input from various counterparts. The contextual performances are time management, prompt decision making, being assertive and human relations such as voluntary behaviors.

Furthermore, the low key performance index among the engineer's would affect the firm's overall performance. This is consistent with the previous literatures that stated the effects of task performance and contextual performance on turnover, job satisfaction (Van Scotter, 2000), rewards (Kiker and Motowidlo,1999; Van Scotter et al., 2000), and overall organizational performance (Borman et al., 1995; Borman \& Motowidlo, 1997; Motowidlo \& Van Scotter, 1994; Van Scotter \& Motowidlo, 1996). Task performance contributes to organizational effectiveness either by transforming the organization's raw materials as a step toward creating the organization's products or by providing necessary service and maintenance functions, such as replenishing the supply of raw materials, distributing its finished products, and providing important planning, coordinating, supervising, and staff functions (Kiker and Motowidlo, 1999). Borman and Motowidlo (1993) argued that contextual performance, on the other hand, contributes to organizational effectiveness by supporting the organizational, social, and psychological context in which the technical core must function.

This study is to act as an eye-opener to the senior management team of the importance of human resource practices and their job performance to the engineers for them to perform. Thus, the objectives of this study are to investigate the relationship and the impact of human resources practices toward job performance among E\&E engineers.

\section{Literature Review}

\subsection{Job Performance}

Job performance, namely task performance and contextual performance, had been considered as an important variable in industrial and organizational psychology (Conway, 1999; Griffin et al., 2000; Van Scotter \& Motowidlo, 1996; Borman, 2004).

Firstly, task performance can be seen as the activities that transform raw materials into the goods and services that are the organization's products (Motowidlo et al., 1997). Furthermore, the task performance consists of activities that service and maintain the technical core by replenishing its supply of raw materials; distributing its finished products; or providing important planning, coordination, supervising, or staff functions that enable it to function effectively and efficiently. Thus, task performance bears a direct relation to the organization's technical core, either by executing its technical process or by maintaining and serving its technical requirements.

Secondly, contextual performance as individual efforts that are not directly related to their main task function (Werner, 2000). Moreover, contextual performance is conceptualized as being under the motivational control of individuals and less constrained by work characteristics than task performance (Borman \& Motowidlo, 1993). It is generally assumed that individuals can engage in contextual activities if they wish and that this choice reflects individual differences in motivation (Motowidlo et al., 1997). Contextual performance behaviors involving persistence, effort, compliance, and self-discipline might enhance the effectiveness of individual workers and managers (Motowidlo et al., 1997), coworkers' and supervisors' productivity (Borman, 2004).

\subsection{Human Resources Practices}

\subsubsection{Organizational Activities Participation}

Participation in organizational activities and the opportunity to voice one's opinion gave employees a degree of control over decisions that concern their work. By doing so, the organization entrust the employee to make decisions in the organization's interest, which implies that the organization both trusts the employee as well as values his/her contribution. 


\subsubsection{Autonomy}

Autonomy referred to employees' perceived control over how they carry out their job, including scheduling, work procedures, and task variety. Autonomy has traditionally been highly valued in Western culture (Hogan, 1975). Moreover, previous research has shown that autonomy has direct relationships with performance (Fried \& Ferris, 1987; Liden, Wayne, \& Sparrowe, 2000).

\subsection{Theoretical Framework}

Figure 1 depicts the study's framework that associates human resource practices, namely engineers' participation in related activities and autonomy with their job performance, namely task performance and contextual performance.

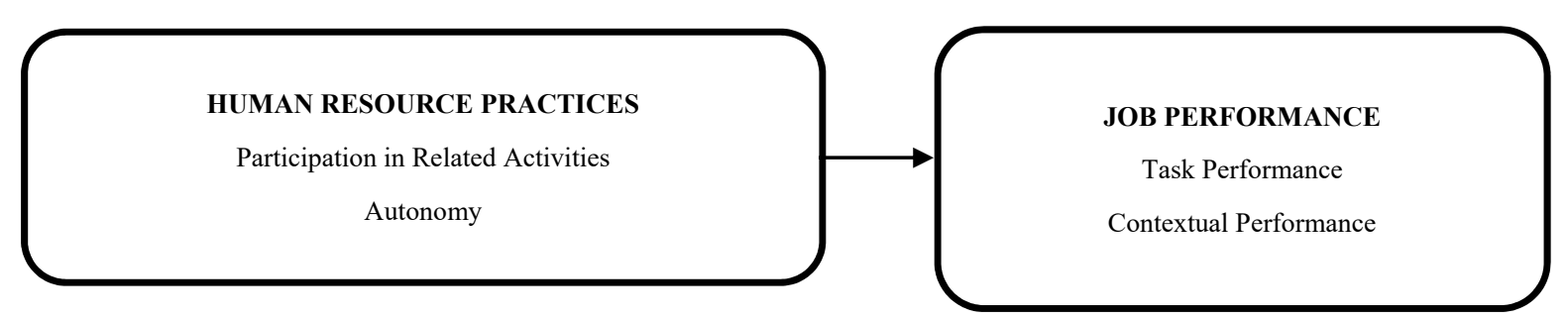

Figure 1. Study's framework

\subsection{Hypotheses}

This study develops the hypotheses in exploring the impact of participation in related activities and autonomy of human resources practices toward task performance and contextual performance of job performance among engineers.

$\mathrm{H}_{1}$ : Engineers' participation in related activities of human resource practices has a significant relationship with task performance.

$\mathrm{H}_{2}$ : Engineers' autonomy of human resource practices has a significant relationship with task performance.

$\mathrm{H}_{3}$ : Engineers' participation in related activities of human resource practices has a significant relationship with contextual performance.

$\mathrm{H}_{4}$ : Engineers' autonomy of human resource practices has a significant relationship with contextual performance.

\section{Methodology}

The study was conducted on the E\&E engineers in the Bayan Lepas Industrial Zone in Penang, Malaysia. A total of 1,100 self-administered questionnaires were distributed to engineers $E \& E$ manufacturing organizations. Moreover, engineers who had worked in the manufacturing companies more than 6-month were considered to take part in this study. Furthermore, this study defined engineers as who were having engineering qualifications either certificates, degree, and master.

\subsection{Research Tools}

Table 1 depicts the list of adapted and adopted various research tools for this study. The human resource practices had been examined on engineers' participation in related activities and autonomy.

Table 1. Research tools' reliability

\begin{tabular}{|c|c|c|c|}
\hline Variables & Source & Items & $\alpha$ \\
\hline Participating in Activities & Govino (2005) & 5 & 0.79 \\
\hline Autonomy & Conway \& Monks (2008) & 4 & 0.88 \\
\hline Contextual Performance & Hochwarter et al. (2004) & 8 & 0.94 \\
\hline
\end{tabular}


For the engineers' participation in related activities, the works of Govino (2005) had been used with an $\alpha$ of 0.79. The engineers were asked on the following questions:

1. I have participated in the selection of new employees.

2. I have participated in the training of new employees.

3. I have been involved in interviewing candidates before they are hired in my company.

4. I participate in a problem-solving discussion regarding work-related issues.

5. I am encouraged to bring up ideas to help accomplish my company's goals.

For the engineers' autonomy, the works of Conway \& Monks (2008) had been used with an $\alpha$ of 0.79 . The engineers were asked on the following questions:

1. I have flexibility in deciding how my job should be done.

2. I have the opportunities to make suggestions about issues affecting my work.

3. I have the opportunities to choose my job assignments.

4. I influence in deciding the way my work is organized.

For the engineers' task performance, the works of Williams and Anderson (1991) had been used with an $\alpha$ of 0.95. The engineers were asked on the following questions:

1. Fulfils responsibilities specified in the job description.

2. Adequately completes assigned duties.

3. Perform tasks that are expected of him/her.

4. Meets formal performance requirements of the job.

5. Engages in activities that will directly affect his/her performance evaluation.

6. Neglects aspects of the job he/she is obligated to perform.

7. Fails to perform essential duties.

For the engineers' task performance, the works of Hochwarter et al. (2004) had been used with an $\alpha$ of 0.94 . The engineers were asked on the following questions:

1. Help others without being asked.

2. Treat others properly.

3. Praise others.

4. Support and encourage others.

5. Put in extra hours to get the work done on time.

6. Tackle difficult work assignments enthusiastically.

7. Work harder than necessary.

8. Persist in overcoming obstacles to complete tasks.

\section{Data Analysis and Results}

A total of 181 questionnaires were collected and yielding response rate of $16.5 \%$. From these, a total of 150 questionnaires were used with a useable rate of $13.6 \%$. These data were analyzed using SPSS on the factor analysis, reliability analysis, demographic analysis, correlations analysis, and regression analysis.

\subsection{Factor Analysis}

Exploratory principal component factor analyses with varimax rotation were used to discover the underlying structure on dimensions for the human resource practices, namely participation in activities and autonomy. Factor analysis is a technique to achieve parsimony through the identification of the smallest number of descriptive terms to explain the maximum amount of common variance in a component matrix (Petty, 1995). Hair et al. (1998) highlighted that factor analysis is also used to establish the best measure for validation purpose. Communality values of all items were above 0.50 . According to Hair et al. (1998), only communality values of 0.50 and above are considered acceptable, one item was dropped due to low communality. 


\subsubsection{Factor Analysis of Participation in Activities}

Five items were used to measure this criterion variable. Initial results of the within factor analysis on the five items came out with dual factors. Two factors were extracted.

The first factor represented by two items. They were (1) "I have participated in the training of new employees", and (2) "I have been involved in interviewing candidates before they are hired in my company". This factor with eigenvalue 1.17 accounted for $36.26 \%$ of the total variance in the data. Factor loadings for items in this factor are 0.86 and 0.84 as depicted in Table 2. This factor was labelled as participation in human resource-related activities.

The second factor represented by two items. They were (1) "I participate in a problem-solving discussion regarding work-related issues" and, (2) "I am encouraged to bring up ideas to help my company's goals". This factor with eigenvalue 1.81 accounted for $38.22 \%$ of the total variance in the data. Factor loadings for items in this factor are 0.87 for both items. This factor was labelled as participation in work-related activities.

Table 2. Results of factor analyses on participation in activities

\begin{tabular}{lll}
\hline & \multicolumn{2}{l}{ Factor Loading } \\
\cline { 2 - 3 } Items & F1 & F2 \\
\hline I have participated in the training of new employees & 0.15 & 0.86 \\
I have been involved in interviewing candidates before they are hired in my company & 0.16 & 0.84 \\
I participate in a problem-solving discussion regarding work-related issues & 0.87 & 0.13 \\
I am encouraged to bring up ideas to help accomplish my company's goals & 0.87 & 0.13 \\
\hline Eigenvalues & 1.81 & 1.17 \\
Total Variance Explained (\%) & 36.26 & 38.22 \\
KMO & 0.53 & \\
Bartlett's Test of Sphericity & 91.09 & \\
\hline
\end{tabular}

\subsubsection{Factor Analysis of Autonomy}

Four items were used to measure this criterion variable. Initial results of the within factor analysis on the four items came out with a single factor. The results of the principal component s analysis and the reliability test are given in Table 3.

Table 3. Results of factor analyses on autonomy

\begin{tabular}{ll}
\hline Items & Factor Loadings \\
\hline I have flexibility in deciding how my job should be done & 0.71 \\
I have the opportunities to make suggestions about issues affecting my work & 0.67 \\
I have the opportunities to choose my job assignments & 0.70 \\
I influence in deciding the way my work is organized & 0.80 \\
\hline Eigenvalues & 2.09 \\
Total Variance Explained (\%) & 52.10 \\
KMO & 0.72 \\
Bartlett's Test of Sphericity & 96.82 \\
\hline
\end{tabular}

\subsection{Reliability Analysis}

Table 4 summarized the study's Cronbach's Alpha after the factor analysis. The participation in activities, one-item was dropped from the initial tool. Moreover, the participation in activities was divided into the participation in HR-related activities with 2-item with an $\alpha=0.82$ and participation in work-related activities with an $\alpha=0.69$. The autonomy with the 4-item tool had an $\alpha=0.67$. On the other hand, the task performance with 5-item after 2 -item were dropped gave an $\alpha=0.80$. The items were (1) "adequately completes assigned duties" and (2) "perform tasks that are expected of him/her". And, the contextual performance with 5-item after 3 -item were dropped gave an $\alpha=0.86$. The items were (1) "help others without being asked", (2) "treat others properly", and (3) "tackle difficult work assignments enthusiastically". 
Table 4. Reliability analysis

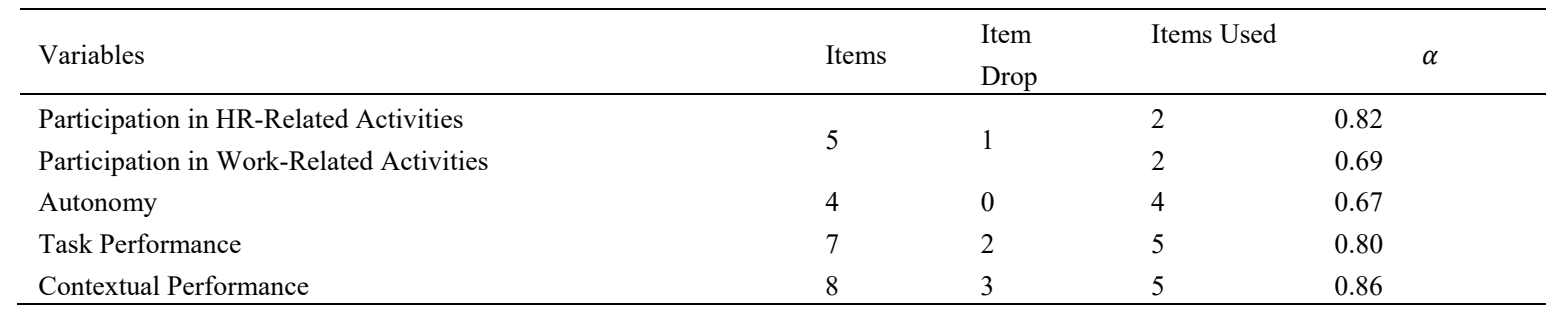

\subsection{Revised Framework and Hypotheses}

The factor analysis had the study's framework as depicted in Figure 2.

HUMAN RESOURCE PRACTICES

Participation in HR-Related Activities

Participation in Work-Related Activities

Autonomy

\section{JOB PERFORMANCE}

Task Performance

Contextual Performance

Moreover, the study's hypotheses were revised as below:

$\mathrm{H}_{1}$ : Engineers' participation in HR-related activities of human resource practices has a significant relationship with task performance.

$\mathrm{H}_{2}$ : Engineers' participation in work-related activities of human resource practices has a significant relationship with task performance.

$\mathrm{H}_{3}$ : Engineers' autonomy of human resource practices has a significant relationship with task performance.

$\mathrm{H}_{4}$ : Engineers' participation in HR-related activities of human resource practices has a significant relationship with contextual performance.

$\mathrm{H}_{5}$ : Engineers' participation in work-related activities of human resource practices has a significant relationship with contextual performance.

$\mathrm{H}_{6}$ : Engineers' autonomy of human resource practices has a significant relationship with contextual performance.

\subsection{Demographic Analysis}

The demographic analysis was done on the engineers' gender, ethnicity, marital status, age, education, engineering specialization, organizational tenure, and working tenure is depicted in Table 5.

Table 5. Demographic analysis

\begin{tabular}{|c|c|c|}
\hline Item & $\mathrm{n}$ & $\%$ \\
\hline \multicolumn{3}{|l|}{ Gender } \\
\hline - $\quad$ Male & 96 & 64.0 \\
\hline - $\quad$ Female & 54 & 36.0 \\
\hline \multicolumn{3}{|l|}{ Ethnicity } \\
\hline - $\quad$ Malay & 42 & 28.0 \\
\hline - $\quad$ Chinese & 82 & 54.7 \\
\hline Indian & 24 & 16.0 \\
\hline Others & 2 & 1.3 \\
\hline \multicolumn{3}{|l|}{ Marital Status } \\
\hline - $\quad$ Married & 54 & 36.0 \\
\hline Single & 96 & 64.0 \\
\hline
\end{tabular}




\begin{tabular}{|c|c|c|}
\hline \multicolumn{3}{|l|}{ Age (years old) } \\
\hline - $\quad 18$ to 25 & 26 & 17.3 \\
\hline - $\quad 26$ to 35 & 110 & 73.3 \\
\hline - $\quad 36$ to 45 & 13 & 8.7 \\
\hline - $\quad 46$ and above & 1 & 0.7 \\
\hline \multicolumn{3}{|l|}{ Education } \\
\hline - National Certificate & 8 & 5.3 \\
\hline - Professional Certificate & 5 & 3.3 \\
\hline - $\quad$ Engineering Diploma & 10 & 6.7 \\
\hline - $\quad$ Engineering Degree & 114 & 76.0 \\
\hline - $\quad$ Master in Engineering & 13 & 8.7 \\
\hline \multicolumn{3}{|l|}{ Engineering Specialization } \\
\hline - $\quad$ Electronic \& Electrical & 97 & 64.7 \\
\hline - $\quad$ Mechanical & 38 & 25.3 \\
\hline - $\quad$ Chemical & 3 & 2.0 \\
\hline - $\quad$ Others & 12 & 8.0 \\
\hline \multicolumn{3}{|l|}{ Organizational Tenure (years) } \\
\hline - $\quad$ Less than 1 year & 33 & 22.0 \\
\hline - 2 to 5 years & 102 & 68.0 \\
\hline - 6 to 9 years & 13 & 8.7 \\
\hline - $\quad$ Above 10 years & 2 & 1.4 \\
\hline \multicolumn{3}{|l|}{ Working Tenure (years) } \\
\hline - $\quad$ Less than 1 year & 15 & 10.0 \\
\hline - $\quad 2$ to 5 years & 85 & 56.7 \\
\hline - 6 to 9 years & 34 & 22.7 \\
\hline - 10 to 13 years & 10 & 6.7 \\
\hline - $\quad$ Above 14 years & 6 & 4.1 \\
\hline
\end{tabular}

Interestingly in the context of $\mathrm{E} \& \mathrm{E}$ manufacturing sector, the majority of the employees were male $(\mathrm{n}=96,64 \%)$ as compared to female $(n=54,36 \%)$. Moreover, the majority of the engineers were Chinese $(n=82,54.7 \%)$ as compared to 42 employees (28\%) were Malay, 24 employees (16\%) were Indian, and 2 employees (1.3\%) were under other ethnicities. Engineers who were not married $(\mathrm{n}=96,64 \%)$ has overwhelmed 54 employees $(36 \%)$ who were married. Majority of the engineers were aged between 26 to 35 years old $(n=110,73.3 \%)$ as compared to 26 employees (17.3\%) were between 18 to 25 years old, 13 employees $(8.7 \%)$ were between 36 to 45 years old, and one employee was 46 years old and above $(0.7 \%)$. As an engineer, majority of the them were having an engineering degree $(n=114,76 \%)$ as compared to other qualifications, namely master in engineering $(n=13$, $8.7 \%)$, engineering diploma $(n=10,6.7 \%)$, national certificate $(n=8,5.3 \%)$, and professional certificate $(n=5$, $3.3 \%)$. Majority of the engineers were specializing in Electronic \& Electrical $(\mathrm{n}=97,64.7 \%)$ as compared to Mechanical $(n=38,25.3 \%)$, Chemical $(n=3,2 \%)$, and other specializations $(n=12,8 \%)$. Majority of them had been with the current organization between 2 to 5 years $(\mathrm{n}=102,68 \%)$. The remaining engineers had been working less than 1 year $(n=33,22 \%), 6$ to 9 years $(n=13,8.7 \%)$, and above 10 years $(n=2,1.4 \%)$ with the current manufacturing. Finally, their total working tenure as an engineer were between 2 to 5 years $(\mathrm{n}=85$, $56.7 \%)$; and followed by 6 to 9 years $(n=34,22.7 \%)$, less than 1 year $(n=15,10 \%), 10$ to 13 years $(n=10,6.7 \%)$, and above 14 years $(\mathrm{n}=6,4.1 \%)$.

\subsection{Correlations Analysis}

The correlations analysis was conducted between participation in HR-related activities, participation in work-related activities, and autonomy of human resource practices and task performance and contextual performance of job performance among the E\&E engineers.

Table 6 depicts the correlation analysis results of human resource practices and job performance. Engineers indicated that autonomy had a significant and low relationship $(\mathrm{r}=0.19)$ with task performance. Unfortunately, participation in HR-related activities $(\mathrm{r}=-0.04)$ and participation in work-related activities $(\mathrm{r}=0.15)$ of engineers had no significant relationship with task performance. On the other hand, the engineers indicated that their contextual performance had a low significant relationship with participation in HR-related activities $(\mathrm{r}=0.21)$ and a moderate significant relationship with autonomy $(\mathrm{r}=0.34)$. 
Table 6. Correlations analysis

\begin{tabular}{llllll}
\hline Variables & 1 & 2 & 3 & 4 & 5 \\
\hline $1 \quad$ Participation in HR-Related Activities & 1 & $* 0.19$ & $* * 0.26$ & -0.04 & $* 0.21$ \\
$2 \quad$ Participation in Work-Related Activities & & 1 & $* * 0.28$ & 0.15 & 0.08 \\
$3 \quad$ Autonomy & & & 1 & $* 0.19$ & $* * 0.34$ \\
$4 \quad$ Task Performance & & & & & $*$ \\
$5 \quad$ Contextual Performance & & & & & \\
\hline Note. & $* \mathrm{p}<.05 ; * \mathrm{p}<.01$.
\end{tabular}

\subsection{Regression Analysis}

Regression analysis was conducted between participation in HR-related activities, participation in work-related activities, and autonomy of human resource practices and task performance and contextual performance of job performance among the $\mathrm{E} \& \mathrm{E}$ engineers

In the context of task performance, the engineers had the $\mathrm{R}^{2}$ value showed $22 \%$ for the dependent variable of task performance, which was explained by the participation in HR-related activities, participation in work-related activities, and autonomy of human resource practices. This means that $78 \%$ of the variance for task performance was explained by other unknown additional variables that have not been explored. The regression model $(\mathrm{F}=3.60$, $\mathrm{p}<0.01$ ) was proven to be a significant model due to the $\mathrm{F}$ ratio being significant in predicting task performance. Moreover, participation in HR-related activities $(\beta=0.50, p>0.10)$ was not a significant predictor of task performance for the engineers. On the other hand, participation in work-related activities $(\beta=0.19, \mathrm{p}>0.01)$ and autonomy $(\beta=0.21, \mathrm{p}>0.05)$ were a significant predictor of task performance for the engineers.

In the context of contextual performance, the engineers had the $\mathrm{R}^{2}$ value showed $24 \%$ for the dependent variable of contextual performance, which was explained by the participation in HR-related activities, participation in work-related activities, and autonomy of human resource practices. This means that $76 \%$ of the variance for contextual performance was explained by other unknown additional variables that have not been explored. The regression model $(\mathrm{F}=4.20, \mathrm{p}<0.01)$ was proven to be a significant model due to the $\mathrm{F}$ ratio being significant in predicting contextual performance. Moreover, the participation in HR-related activities $(\beta=0.30, p<0.01)$ and autonomy $(\beta=0.23, p>0.01)$ were a significant predictor of contextual performance for the engineers. On the other hand, participation in work-related activities $(\beta=-0.12, p>0.01)$ was not a significant predictor of contextual performance for the engineers.

Table 7. Regression analysis

\begin{tabular}{|c|c|c|c|c|}
\hline \multirow{3}{*}{ Human Resource Practices } & \multicolumn{4}{|c|}{ Job Performance } \\
\hline & \multicolumn{2}{|c|}{ Task Performance } & \multicolumn{2}{|c|}{ Contextual Performance } \\
\hline & $\beta$ & Sig. & $\beta$ & Sig. \\
\hline Participation in HR-Related Activities & 0.50 & Nil & 0.30 & 0.01 \\
\hline Participation in Work-Related Activities & 0.19 & 0.01 & -0.12 & Nil \\
\hline Autonomy & 0.21 & 0.05 & 0.23 & 0.01 \\
\hline $\mathrm{R}^{2}$ & 0.22 & & 0.24 & \\
\hline Adj. $R^{2}$ & 0.16 & & 0.19 & \\
\hline F-Change & 3.60 & & 4.20 & \\
\hline Sig.-F & 0.01 & & 0.01 & \\
\hline
\end{tabular}

Therefore, hypothesis $\mathrm{H}_{1}$ is not supported in explaining the engineers on their participation in HR-related activities toward task performance. On the other hand, hypothesis $\mathrm{H}_{2}$ and $\mathrm{H}_{3}$ are supported in explaining the engineers on their participation in work-related activities and autonomy toward task performance. On the other hand, hypothesis $\mathrm{H}_{4}$ and $\mathrm{H}_{6}$ are supported in explaining the engineers on their participation in HR-related activities and autonomy toward contextual performance. Unfortunately, hypothesis $\mathrm{H}_{5}$ is not supported in explaining the engineers on their participation in work-related activities toward contextual performance. 
Table 6. Regression analysis results

\begin{tabular}{ll}
\hline Hypothesis & Result \\
\hline $\mathrm{H}_{1}$ : Engineers' participation in HR-related activities of human resource practices has a significant & Not Supported \\
relationship with task performance & \\
$\mathrm{H}_{2}:$ Engineers' participation in work-related activities of human resource practices has a significant & Supported \\
relationship with task performance & \\
$\mathrm{H}_{3}: \quad$ Engineers' autonomy of human resource practices has a significant relationship with task & Supported \\
performance & \\
$\mathrm{H}_{4}: \quad$ Engineers' participation in HR-related activities of human resource practices has a significant & \\
relationship with contextual performance & Supported \\
$\mathrm{H}_{5}: \quad$ Engineers' participation in work-related activities of human resource practices has a significant & \\
relationship with contextual performance & Not Supported \\
$\mathrm{H}_{6}: \quad$ Engineers' autonomy of human resource practices has a significant relationship with contextual & \\
performance & Supported \\
\hline
\end{tabular}

\section{Discussion \& Conclusion}

Engineers indicate on their perspective toward task performance and contextual performance of their job performance. Task performance involves patterns of behavior that are directly involves in producing services or goods, or activities. When employees use knowledge and technical skills to accomplish a task, they are engaging in task performance (Van Scotter \& Motowidlo, 2000). Although the engineers are given the opportunities to be part of their organizations' human resource activities, unfortunately, the opportunities given has not given any positive and beneficial impact on their task performance as an engineer in terms of their skills and knowledge. Interestingly, if the engineers perceived that they need to maintain a good working relationship, then they will put their extra effort in completing their involvement. Thus, the engineers have been positive toward their contextual performance in their organization. Moreover, work autonomy was found to be significantly predicting task performance. On autonomy, the findings from this study showed that if the employees assessed that they are given the amount of flexibility in deciding how their job should be done and had the opportunities to make suggestions about issues affecting their job, they tend to show greater job performance (Conway \& Monks, 2008).

In other words, the engineers are willing to help the organizations' human resource department in the new engineers' in the interview process before them being employed in their organization. Moreover, these engineers are also willing to be part of the human resource department in terms of proving training to the new engineers who are employed with the organization. Furthermore, the organizations' human resource department should get their engineers to be involved in the organizations' as the panels in the interview and selection process, and also involved in the organizations' training for the new engineers. This has shown that the current engineers in the organizations are willing to be part of their organizations' development in determining the selection, selection, and training done by the human resource department. The results implies that technical engineers who have higher assessment by their organizations would be more likely to exhibit contextual performance such as discretionary behaviors not formally required by any particular job, yet helping the social context of all jobs (Motowidlo et al., 1997; Van Scotter \& Motowidlo, 1996).

On the other hand, the top management of the organizations should not get their engineers to be involved in the organizations' problem solving of works and the determination of the organizations' directions. The engineers are not interested in these work-related activities as they can be considered not interested or had no particular work-related experience in solving the organizations' work issues and future directions. Finally, the engineers want them to have autonomy in their job as an engineer that is associated with their task performance and contextual performance. They want to have the say on their works in terms of scheduling, work procedures, and task variety.

\section{Acknowledgements}

The author would like to thank you for the Universiti Sains Malaysia on their support and grant provided. Ref. no. 1001/PJJAUH/8016077.

\section{References}

Borman, W. C. (2004). The concept of organizational citizenship. Current Directions in Psychological Science, 13(6), 238-241. https://doi.org/10.1111/j.0963-7214.2004.00316.x 
Borman, W. C., \& Motowidlo, S. J. (1993). Expanding the criterion domain to include elements of contextual performance. In Schmitt, N. and Borman, W. C. (Eds.), Personnel Selection in Organizations. New York: Jossey-Bass.

Borman, W. C., \& Motowidlo, S. J. (1997). Task and contextual performance: The meaning for personnel selection research. Human Performance, 10, 99-109. https://doi.org/10.1207/s15327043hup1002_3

Borman, W. C., White, L. A., \& Dorsey, D. W. (1995). Effects of rate task performance and interpersonal factors on supervisor and peer performance rating. Journal of Applied Psychology, 80(1), 168-177. https://doi.org/10.1037/0021-9010.80.1.168

Conway, E., \& Monks, K. (2008). HR practices and commitment to change: an employee-level analysis. Human Resource Management Journal, 18(1), 87-88. https://doi.org/10.1111/j.1748-8583.2007.00059.x

Conway, J. M. (1999). Distinguishing contextual performance from task performance for managerial jobs. Journal of Applied Psychology, 84, 3-13. https://doi.org/10.1037/0021-9010.84.1.3

FMM. (2007/2008). FMM-MATRADE Industry Directory, Electronics and Electricals Malaysia. Thumbprints UTD Sdn. Bhd.: Rawang, Selangor.

Fried, Y., \& Ferris, G. R. (1987). The validity of the job characteristics model: A review and meta-analysis. Personnel Psychology, 40, 287-322. https://doi.org/10.1111/j.1744-6570.1987.tb00605.x

Govino, M. (2005). Understanding the impact of HR Practices on Employee Attitudinal and Behavioral Outcomes: The Role of POS. University of Illinois: Chicago.

Griffin, M. A., Neal, A., \& Neale, M. (2000). The contribution of task performance and contextual performance to effectiveness: investigating the role of situational constraints. Applied Psychology: An International Review, 49(3), 517-533. https://doi.org/10.1111/1464-0597.00029

Hair, Jr. J. F., Anderson, R. E., Tatham, R. L., \& Black, W. C. (1998). Multivariate data analysis (5th ed.). Upper Saddle River, NJ: Prentice-Hall.

Hochwarter, W. A., Kacmar, C., Perrere, P. L., \& Johnson, D. (2004). Perceived organizational support as a mediator of the relationship between politics perceptions and work outcomes. Journal of Vocational Behaviors, 63, 438-456. https://doi.org/10.1016/S0001-8791(02)00048-9

Hogan, R. (1975). Theoretical egocentrism and the problem of compliance. American Psychologist, 30, 533-540. https://doi.org/10.1037/h0076638

Kiker, D. S., \& Motowidlo, S. J. (1999). Main and interaction effects of task and contextual performance on supervisory reward decisions. Journal of Applied Psychology, 84(4), 602-609. https://doi.org/10.1037/0021-9010.84.4.602

Lado, A. A., \& Wilson, M. C. (1994). Human resource systems and sustained competitive advantage: a competency-based perspective. Academy of Management Journal, 19(4), 699-727. https://doi.org/10.5465/amr.1994.9412190216

Liden, R. C., Wayne, S. J., \& Sparrowe, R. T. (2000). An examination of the mediating role of psychological empowerment on the relations between the job, interpersonal relationships, and work outcomes. Journal of Applied Psychology, 85, 407-416. https://doi.org/10.1037/0021-9010.85.3.407

MIDA. (2009). http://www.mida.gov.my/en_v2/index.php?page=ems

Motowidlo, S. J., \& Van Scotter, J. R. (1994). Evidence that task performance should be distinguished from contextual performance. Journal of Applied Psychology, 79, 475-480. https://doi.org/10.1037/0021-9010.79.4.475

Motowidlo, S. J., Borman, W. C., \& Schmit, M. J. (1997). A theory of individual differences in task and contextual performance. Human Performance, 10(2), 71-83. https://doi.org/10.1207/s15327043hup1002_1

Petty, G. C. (1995). Vocational-technical education and the occupational work ethic. Journal of Industrial Teacher Education, 32(3), 45-58.

Van Scotter, J. R. (2000). Relationships of task performance and contextual performance with turnover, job satisfaction, and affective commitment. Human Resource Management Review, 10(1), 79-95. https://doi.org/10.1016/S1053-4822(99)00040-6

Van Scotter, J. R., \& Motowidlo, S. J. (1996). Interpersonal facilitation and job dedication as separate facets of contextual performance. Journal of Applied Psychology, 81, 525-531. 
https://doi.org/10.1037/0021-9010.81.5.525

Van Scotter, J. R., Motowidlo, S. J., \& Cross, T. C., (2000). Effects of task and contextual performance on systematic rewards. Journal of Applied Psychology, 85(4), 526-535. https://doi.org/10.1037/0021-9010.85.4.526

Werner, J. M. (2000). Implications of OCB and contextual performance for human resource management. Human Resource Management Review, 10(1), 3-24. https://doi.org/10.1016/S1053-4822(99)00036-4

Williams, L. J., \& Anderson, S. E. (1991). Job satisfaction and organizational commitment as predictors of organizational citizenship behavior and in-role behaviors. Journal of Management, 17(1), 601-617. https://doi.org/10.1177/014920639101700305

\section{Copyrights}

Copyright for this article is retained by the author(s), with first publication rights granted to the journal.

This is an open-access article distributed under the terms and conditions of the Creative Commons Attribution license (http://creativecommons.org/licenses/by/4.0/). 